\title{
Home/Self/Ecology/Politics [1]
}

Building upon Deleurian philosophy, deep ecology, Carol Ronai's (1995) model of the layered text, and Wendell Berry's post 9/11 writings, I recollect on my story of our West and reflect on the meanings of home for the self and in particular on how environmentally destructive politics problematize the security of ecological space. Based on both fieldwork and autoethnography this essay draws inspiration from Emile Zola's 'J' Accuse"- bis inveterate condemnation of the late 1800s French regime implicated in the Dreyfus scandal. Autoethnographic reflections and ethnographic conversations with inhabitants of V ancouver Island, British Columbia, are layered within the text to blur the boundaries existing between home/self/ecology/politics and to condemn anthropocentric ideologies.

Keywords: Home; Self; Autoethnography; Environment; Deep Ecology. 
La Verité est en marche, et rien ne l'arretera.

$\sim$ Emile Zola.

Few spatial experiences can be as emotionally powerful as becoming lost in a labyrinth. In a labyrinth we find pleasure in suspending the belief that space can be ordered, controlled, and navigated through the vertical instrumental logic that guides our everyday life. In a labyrinth we find comfort in the knowing admission that an exit does exist; an exit that orders our blind movement much like death orders our mundane search for meaning. And yet an experience all the more powerful in its incapacitating potential is possible: the experience of finding home in a labyrinth. Feeling at home in a labyrinth rejects and reverses the panoptic logic that dictates that movement can be uni-directional, that our body can be gazed upon from a god-like vertical vantage point, and that searching is meaningful at all. Finding home in a labyrinth requires rejecting the possibility of an exit and demands finding pleasure in movement through space, rather than in spatial stasis. The labyrinth can then be a home, and is a home to the derelict, the exiled, the vagabond, and the dispersed. These people, many of us, find home in departing but not in returning, for they have nothing to return to.

\section{$* * *$}

Norman Denzin (2003) invited us to write stories of the West. This is my story of our West [2]. This is the story of how I found, lost, and found again my self in the labyrinth that is my own Western frontier. This is a story of my self, my homes, our ecological spaces, and how I live(d) my personal politics. Self, home, ecology, and politics clash, merge, and feed one another as I recollect and reconstruct my story. As I write I deconstruct myself and speak with different voices: the voices of past, present, and future I's and we's. The final product of my writing is a fragmented, yet continuous trace of my self and our spaces, seen through our eyes (yours and mine). The final 
product, much like the process of getting there, is the labyrinth of my/our lost and found self/selves, my/our homes, my/our ecological space, and my/our politics.

I was born twenty-nine years ago in Tuscany, Italy. American film kidnapped my imagination as a child. I wanted to play bowling and drive my corvette to Inspiration point. I wanted diners' burgers and milk-shops' jukebox music. I wanted to explore Yellowstone and ride Californian waves. I had none of that where I was. I needed a new home and a new self. The American frontier had become my own frontier: a land of Coca-Cola and ball-park hot dogs, a land of dreams and possibilities.

Then the Italian military kidnapped my very life for one year. They gave me a cage for a home. They took my self and dressed it in a uniform. My own home became a nowhere land made of broken dreams and ill fate.

The day the let me go I ran away. I was driven to fly, scarred by violent hatred toward my old land and toward my coward, humiliated uniform-ed self. I ran to Seattle, as far North and as far West as I could go, burned by the desire to find new spaces. Self-exiled at twenty-three years of age, I escaped alone and lonely, for I wanted no trace of my old self.

\begin{abstract}
$* * *$
Seattle felt home right away. I had never felt the cold waters of the Pacific Ocean. I had never breathed ocean air and mountain air at the same time. My new home was foreign, and yet familiar. My new self was foreign, yet familiar.
\end{abstract}

I remember riding my bike up the hills of Seattle just to view what was on top. I remember taking the ferry to go nowhere, simply to go somewhere. I remember pinning a copy of the American constitution to my bedroom wall. I remember standing up during the anthem, singing, 
every time, truly believing in the American politics of freedom. I remember finding my self in my new home in the forests along the ocean, in the flag, in my American ID.

Six years had gone by when some time ago I went grocery shopping and felt lost in my shopping cart. I had bought Emmental Swiss cheese, like my grandma always used to give me as a snack when I was a young child. I had bought American fish sticks, made of sticks but doubtfully of fish. I had bought Chinese oyster sauce, always perfect for my favorite Italian dish: orecchiette alle cime di rapa, and I had bought French yoghurt and Indian curry. They say you are what you eat. What in the world am I then? I felt lost at home again; lost in my own labyrinth. Someone had taken away my American self, my American home. What had happened?

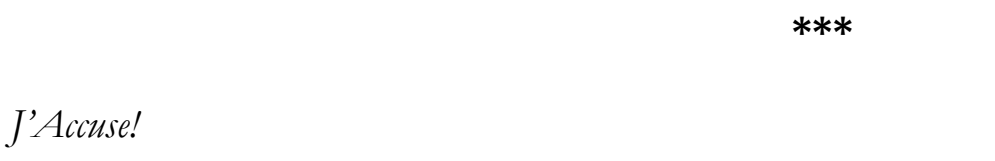

President Bush, you have taken away my home. You took it away with your blood-blinded eyes on that day after September 11 and kept it ever after. Your flag is no longer my flag. Your home is no longer my home. Your "secure" home land is no longer safe for me, no longer my land. You forgot me, Mr. President, and you forgot those who do not believe in your god, in any humanmade, humanly puny, oil-soaked god. This is your holy war: of your deities of greed, power, and of your ethnocentric and anthropocentric ideologies.

I saw one of your soldiers the other day on a foreign TV station, Mr. President. A kid of my age. He was, like me, coming from somewhere in the world. He was neither white, nor black, nor brown. He was grey, the color of death that he worn on his bare skin. Dead: lying half naked on the sweltering ground of Iraq to defend your god. He was homeless, no longer with his ocean, nor his mountains, or plains, or family. He reminded me of me, in a way. I am alive here in America, but just as homeless. 
Have you ever seen humans refusing to abide by their will to power, Mr. President? You have not, for it's war, all the time. Forget your "America," forget Al Qaeda. I do not stand united: I am against you and against them, for both of you are against my self/home/ecology/politics. There can be no war, for there never is peace, Mr. President. The war of your politics everyday pierces through our homes with its sharp technological needles; it burns our selves with its rhetoric of freedom and democracy veiled in conquest and liberation. Fire seethes, brands the planet everyday, with or without the latest "war." Where is peace in all this? Where was it ever? Where can I find a home that isn't chocked by your fumes? Where can I be myself with our nature?

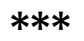

I knew it was time to leave again, that day. Time to find a new self, a new home, a new ecological niche, a new politics. Time to go farther West, and farther North. Time to find a new self/home/ecology/politics in my own labyrinth.

I recollect stepping on Vancouver Island for the first time and feeling home. Much like I felt in Seattle that one night I felt on Vancouver Island, British Columbia years later: I had found again my new home/self.

I now live as a derelict, as an exiled, as a vagabond, as a dispersed, as a Simmelian stranger among friendly strangers. We are at home in the labyrinth, together [3]. A new ecological space in the labyrinth has become our home because we have fantasized about it, dreamed of it, and sought after it, for a lifetime. Here, in this new home, we find our true selves, long before the ferry ride to the island, long before the intercontinental flight.

Many of us have lived in different places and only moved to Vancouver Island after traveling a long and contorted labyrinthine path. Others have grown here, and dreamed about it just as much. We all love what we have found. We love living here because of the mountains, the air, and the 
exotic landscape. Our island is isolated. It is the furthest west you can go; it is a great escape. People search for something exotic or unique all their life and we have found it at home, right here.

The feeling we get when we step onto our island is like nothing else, it is relaxing and refreshing. Time seems to slow down. This is a life-world flooded with the radiance of a meaningful milieu; its identity is our identity, our being different from elsewhere. Then, the memory of a day in the cities on the mainland turns into the nightmare of a day spent in traffic, caught between anonymous strangers, trapped underneath towering giants of cement. The return is a much welcomed experience. As the metropolis is left behind, the body slows down, comforted by the glowing sight of familiar signs. That glow is the becoming of home, the creation of meaning out of space. Difference is found in the foreign, in the external, in distant space, in the Other. It is a separate world here from there. Nature keeps us safe, as it is all around us: in the clean air, in the limited traffic, in the small pollution. Here at home people have time, and when you pass others on the street, they always say hello. People in the city drive hours to find a parking spot at a city park. Here, we are living in a park. It feels natural, the right place to be. Here we can be ourselves, who we have chosen to become by coming here or by growing here.

\section{$* * *$}

Our self: a meaningful landscape of no-return. As new spaces become meaningful, as new selves become our home, as new politics become personal guides, other territories remain outside. We create our differences, arrange them, and seize them. We are unique here at home, with our true selves, always lost and found in the labyrinth, then lost again and found again, always becoming something else, somewhere else.

Our identity is a territorial claim, a marker of a different meaningful space, an act of territorialization (Deleuze and Guattari, 1987). We can feel home because we feel an outward continuous becoming with our nature and an inward, fluid and growing sense of being and having 
been our selves. We came here and we like to think that it was our choice, and we like to think that we can always leave and embrace a new part of who we are, where we are, and where we might have always been.

Home is mundane poetry, poetry of attachment, joy, melancholia, and hope; the unrepresentational poetry of reforming ourselves through entering the labyrinth, and of saying yes to our never-waning desire to find our home in it, to the nature of movement to which we belong. Home/self is an ecological lee. A lee from homelessness, and anonymity. A lee from the scars of destruction branded in fire and in fumes, in gases and in filth. A lee which - some seem to forget does not belong to us. It is we, rather, who belong to our home, our earth.

\section{$* * *$}

Home/self is repetition. Home/self may be here now, there in a distant future, elsewhere in our past. Home/self is a treasured ecological space, a meaningful landscape, a multimodal experience of familiar sights, sounds, smells, stories, and feelings. Home/self is rhythm, always ineffable (Wise, 2000).

For us, now, home is here on Vancouver Island. At our favorite park in Nanaimo we walk right along the ocean, and tune into lazy waves crashing ashore. At our favorite beach in Tofino we listen to the quiet music of waves crashing ashore. Sounds like home. We remember a story told by Gilles Deleuze and Felix Guattari (1987) in A Thousand Plateaus, the story of a child in the dark. The child, "gripped with fear, comforts himself by singing under his breath" (Deleuze and Guattari, 1987: 311). The song calms the child down, allows him to feel a comfortable stability against the chaos and the unknown. The humming of the song is the beginning of familiarity and order. The song turns a foreign space into a familiar one, yet it is not the song itself but rather the repetition of the few elementary verses which marks that space and creates a milieu. The milieu is "a block of space-time constituted by the periodic repetition of the component" (Deleuze and Guattari, 1987: 
313). The song, much like the sound of the ocean in the background of a slow Sunday afternoon walk or a late night ferry ride constitutes a home, and installs a sense of comfort in an otherwise strange space. In this sense, home ceases to be the place from where we come. Home is not just where we are, but rather what we make out of a place, how we live a territory and how we interpret a territory to express who we are and who we intend to become.

\section{$* * *$ \\ This is our home. Insert picture 1 about here (see attached file).}

You see no houses here, with their gadgets and machines, with their energies destructive of land and air and water. You see home neither as waste, nor as destruction (see Berry 1996).

Our oceans, forests, shores, the fudge stand at the Friday market equally mark our space. Familiar sounds, sights, and smells create familiar milieus. We make our space meaningful through a number of signs. In and of itself after all the Strait of Georgia which separates Vancouver Island from the mainland is a mirror of water, one like many, but what makes it our road home is our ordering, organizing, shaping into memory, our claim that it is a marker, a forceful milieu that transcends its physical properties. This is a space that is meaningful for us as it is a space that is constantly moving, becoming, changing with growing discursive practices. From Mount Washington to the Pacific Rim National Park, from Port Hardy's fisheries to Victoria's waterfront, to us Vancouver Islanders these spaces are marked by the feeling of intimacy, by the sense of familiarity. The closeness of nature is very important to us; it would be strange not to live near the ocean and mountains. Our homes, territory, identity, biography, history, are deeply interconnected. We live our territory, speak it, experience it, manipulate it, and how we live it, how we speak of it, how we manipulate it speaks as to who we are, and shapes it as much as it shapes us. "To live means to leave traces" as Benjamin put it (quoted in Boym, 1994: 150). 


\begin{abstract}
$* * *$
It is repetition and habit that make a self/home. Deleuze and Guattari (1987) refer to this repetition and force of habit as the refrain, the pattern of sound, smell, touch, taste, and sight which makes a space significant. Our self/home is here in the unique wildlife and our peaceful forests, in the cold ocean waters and in the rivers and lakes, in the winter rains and the bluer than blue summer skies. Not in the immanence of nature, but rather in its growth. Our self/home is in the diversity of our flora and fauna, in sighting our unique albino raccoons and omnipresent bald eagles. Our self/home is in nature's constant struggle for survival, our struggle to become. Our self/home is in the repetition of sounds and visions, in feeding a hummingbird and helping it find its way back outdoors. Our self/home is in seeing the same family of deer everyday hunting for greener grass in our neighbor's yard, just around the turn of the road by the lagoon.
\end{abstract}

In nature we find spaces, places we call self/home. There is no separation between human kind and our ecological habitat. Through our nature we exist. Through it we resist the unnatural: murderous pollution, tragic waste, self-annihilating accumulation, and appalling disrespect of all that is naturally sacred. Our environment, our natural spaces, our homes are our origins: a plurality of differences, an ever-lasting tension toward becoming and toward the eternal return to nature (see Berry 1990).

When man imposes himself at the center of universe there is no democracy: there is only despotic anthropocracy. Anthropocentrism constructs our planet as our eternal Other, and forgets it. Mr. President, read the planet its eulogy: you can find it in your distorted view of the bible and constitution. Shock us and awe us. Blind us with the fire that blinds your eyes. Find your enemies, burn their land, which is always our home. Find your glory in a shower of gold and oil and force us to flee again. 
Your growing economy is opposed to my/our becoming our self/selves in our ecological space here at home in our planet, Mr. President. Expand your economy, and we will have to run for cover, once again. Let your acid rain start and we'll patiently find a stronger lee for our self, and then another one, and then one farther, until we have all reached our westernmost and northernmost end. So, cover our thirst for "peace" in tar, Mr. President; build a newer highway to hell and profit from it. So we can get there richer, faster, riding a damaged boat on the shallow depth of your ideologies. Every dream we dreamt is lost, everyday.

Young children in New Delhi draw pictures of their friends playing ball under a polluted grey sky. Grey like death. They have never seen a blue sky. The world has crushed down on their home. How long before it is everybody's turn to collapse under a grey sky? You wouldn't want to stare at fear right in your own eyes, in your own home, would you? Then close out your eyes, everyone. Or fight back.

\section{$* * *$}

The truth is marching and nothing will stop it. Not your truth Mr. President, but the truth spoken by your cycle of destruction. Devour your black gold prize. Devour our planet. Build, market, sell, buy, spend, consume, invest, profit, and pray, pray, and pray, and clear more space for the tentacles of your voracious god. Then package a resource-less planet and wrap it in your flag and sell it to the world.

I want no part in this. Another exile will be my answer. I will practice my resistance with my feet, by walking away from the home that you took, by finding another home in another ecological space that you haven't spoiled. Until I/we can flee no more. Until your politics has swallowed our ecological space, until our homes are burned, until my/our becoming dies with our planet. Until the eternal recurrence of the same. 
Our search for home will soon end, for our struggle for becoming ourselves in the labyrinth will soon lead us to find its exit onto the end that you have created Mr. President. Petrified with fear, I feel home is slipping away, once again. Once again at the end of an anthropocentric politics that puts human freedom before ecological freedom. Upon leaving our labyrinth we will return to the same: to the nothing we came from.

I left in search of freedom. I found it, and I lost it. I found it again and I
When despair grows in me
and I wake in the middle of the night at the least sound
in fear of what my life and my children's lives may be,
I go and lie down where the wood drake
rests in his beauty on the water, and the great heron feeds.
I come into the peace of wild things
who do not tax their lives with forethought
of grief. I come into the presence of still water.
And I feel above me the day-blind stars
waiting for their light. For a time




\section{Endnotes}

[1] I owe gratitude to one anonymous reviewer for my title.

[2] I use the pronouns "we" and "us" with different referents throughout this paper. The pronoun "we" may refer to the author and his changing selves, to the community of Vancouver Islanders, as well as to an unspecified collective grounded in ecological communion with our natural environment. I do so in order to create a layered, impressionistic sketch that offers different layers of experience, different subjects of experience and interpretation, and also in order to blur the boundary between writer/research subjects/readers and their separate spaces (see Ronai 1995). I also do so to avoid creating the impression that my home or my ecological space are mine, that is for me, or possessed by me. Rather, it is ours, for we all are of nature.

[3] In order to study the meaning of home I spoke with approximately fifty members of our community, that is, residents of British Columbia's Vancouver Island. Some of them were born and raised on Vancouver Island whereas others immigrated to the island only later in life. I do not identify their words in this text. Their words are our words.

[4] Following Ronai (1995: 397) I "use asterisks to denote a shift to a different temporal/spatial/attitudinal realm."

[5] Publicly available with explicit permission at http://www.gratefulness.org/poetry/peace of wild things.htm Last accessed Monday, April 5, 2004. 


\section{References}

Berry, W. (1985). The peace of wild things. Collected poems. San Francisco: North Point Press.

Berry, W. (1990). What are people for? San Francisco: North Point Press.

Berry, W. (1996). The unsettling of America: Culture and agriculture. Third Edition. San Francisco: Sierra Club books.

Berry, W. (2001). In the presence of fear: Three essays for a changed world. Louisville, KY: Orion society.

Boym, S. (1994). Common places: Mythologies of everyday life in Russia. Cambridge, MA: Harvard University Press.

Deleuze, G. (1994). Difference and repetition. Translated by P. Patton. New York: Columbia University Press.

Deleuze, G. \& Guattari, F. (1987). A thousand plateaus: Capitalism and schizophrenia. Translated by B. Massumi. Minneapolis: University of Minnesota Press.

Denzin, N. (2003). Searching for Yellowstone. Symbolic interaction, 26, 307-313.

Ronai, C. (1995.) Multiple reflections of child sex abuse: An argument for a layered account. Journal of contemporary ethnography, 23, 395-426.

Wise, J. M. (2000). Home: territory and identity. Cultural Studies 14, 295-310. 